\title{
AKAD PEMBIAYAAN MURABAHAH KENDARAAN BERMOTOR PERUSAHAAN PEMBIAYAAN PT. CIMB NIAGA AUTO FINANCE
}

\author{
SYARIFAH SINAGA, SH, M.Hum \\ Fakultas Hukum Universitas Islam Indonesia \\ Email: sarifamcdermott@gmail.com
}

\begin{abstract}
Abstrak
Murabahah adalah suatu jenis pembiayaan dimana perjanjian pembiayaan dilaksanakan dengan menyatakan harga pokok barang dan margin keuntungan yang disepakati oleh penjual dan pembeli. Perbankan syariah dan lembaga pembiayaan syariah sudah jamak menggunakan pembiayaan murabahah, namun bagaimana halnya bila lembaga pembiayaan non syariah menerapkan pembiayaan murabahah dalam kegiatan usahanya. Penelitian ini bertujuan untuk mendapatkan gambaran tentang bagaimana praktek pembiayaan muhasabah diselenggarakan oleh lembaga pembiayaan non syariah dalam hal ini PT. CIMB Niaga Auto Finance. Hasil penelitian ini diharapkan dapat memberikan gambaran mengenai perbedaan antara akad murabahah yang menerapkan prinsip syariah dengan perjanjian pembiayaan konsumen secara konvensional, kedudukan hukum Surat Kuasa untuk membuat Akta Jaminan Fidusia sudah memenuhi prinsip Syariah, serta kekuatan hukum surat pernyataan bersama yang dibuat antara dealer dan perusahaan pembiayaan.
\end{abstract}

\begin{abstract}
Murabaha Contract For Financing Vehicle Purchase In PT. CIMB Niaga Auto Finance Company. Murabaha is a financing product which is a sale and purchase or sale and purchase agreement by declaring main cost of the goods and make a profit (margin) which has been agreed by the seller and the buyer. Sharia banking and finance institution have commonly used murabaha financing in their activities. The aim of this research are to depict on how murabaha financing product is conducted by a non sharia financing institution in this case PT CIMB Niaga Auto Finance. The result of this research hopely can describe the differences between murabaha act which applying sharia principles compare to conventional financing; the state of Power of Attorney on making fiduciary act that perform the sharia banking principles; and legal standing of mutual agreement between the dealer and financing company.
\end{abstract}

Key word: murabahah, pembiayaan kendaraan.

\section{Pendahuluan}


Lembaga Pembiayaan adalah badan usaha yang melakukan kegiatan pembiayaan dalam bentuk penyediaan dana atau barang modal. Pelaksana kegiatan Lembaga Pembiayaan tersebut adalah Bank, Lembaga Keuangan bukan Bank maupun Perusahaan Pembiayaan. Dimana ketiganya dapat melakukan 1 atau lebih jenis usaha Lembaga Pembiayaan. Apabila pelaksana kegiatan tersebut adalah perusahaan pembiayaan maka harus berbadan hukum atau dapat juga berbentuk koperasi dan tentu saja memenuhi persyaratan tertentu. Obyek pembiayaan konsumen adalah barang-barang konsumsi. Meskipun lembaga pembiayaan merupakan lembaga keuangan bersama-sama dengan lembaga perbankan, namun dilihat dari padanan istilah dan penekanan kegiatan usahanya antara lembaga pembiayaan dan lembaga keuangan berbeda. Istilah lembaga pembiayaan merupakan padanan dari istilah bahasa Inggris financing institution. Lembaga pembiayaan ini kegiatan usahanya lebih menekankan pada fungsi pembiayaannya, yaitu dalam bentuk penyediaan dana atau barang modal, dalam kegiatannya tidak menarik dana secara langsung dari masyarakat, dan lembaga pembiayaan kadangkala tidak memerlukan jaminan.

PT. CIMB Niaga Auto Finance adalah perusaahan pembiayaan otomotif yang merupakan anak perusahaan dari PT CIMB Niaga Tbk. Perusahaan ini memiliki izin untuk melakukan empat jenis kegiatan usaha, yaitu sewa guna Usaha (Leasing), Anjak Piutang (Factoring), Usaha Kartu Kredit (Credit Card) dan Pembiayaan Konsumen. ${ }^{1}$

Dalam pembiayaan kredit mobil di perusahaan pembiayaan PT.CIMB Niaga Auto Finance berdasarkan akad yang kami teliti tidak ditegaskan adanya kata Syariah pada nama Perusahaan tersebut, akan tetapi dalam perjanjian yang dilakukan, perusahaan pembiayaan tersebut diatas ternyata melakukan pembiayaan dengan konsep syariah. Hal yang demikian terlihat pada Perjanjian pokok dalam pembiayaan kredit mobil yang digunakan menggunakan Akad Pembiayaan Murabahah. Dalam contoh akta yang menjadi penelitian kelompok kami ini, Perjanjian pokoknya adalah: Akad Pembiayaan Murabahah yang di buat di bawah tangan sedangkan perjanjian accesoir-nya adalah Akta Jaminan Fiducia yang dibuat secara otentik atau akta notariil, dalam akad ini juga dilekatkan surat kuasa penuh dengan hak subtitusi kepada PT CIMB Niaga auto Finance dan Surat Pernyataan Bersama antara Penjual (Dealer) dengan Ny. Muntakiyah selaku konsumen, yang masing-masing dibuat di bawah tangan. Lampiran-lampiran, surat-surat dokumen pendukung lainnya

\footnotetext{
${ }^{1}$ http://www.cnaf.co.id/Profile, hlm.1
} 


\section{LFx Renaissance No. 2 VOL. 1 JULI 2016: 216 - 233}

merupakan satu kesatuan dan bagian yang tidak terpisahkan dari akad pembiayaan murabahah tersebut. $^{2}$

Dalam isi akad murabahah antara PT CIMB Niaga Auto Finance (CNAF) dengan Ny. Muntakiyah (konsumen) ini disebutkan konsumen menyetujui fasilitas pembiayaan untuk pembelian kendaraan bermotor dengan ketentuan CNAF membeli kendaraan untuk dan atas nama konsumen dari penjual dan selanjutnya CNAF menjual kendaraan tersebut kepada KONSUMEN dengan harga yang telah disepakati oleh para pihak, meliputi harga beli kendaraan dari Penjual ditambah keuntungan (margin) untuk CNAF, tetapi tidak termasuk biaya-biaya yang timbul sehubungan dengan pelaksanaan AKAD dan selanjutnya KONSUMEN membayar harga yang telah disepakati tersebut dengan cara mengangsur dalam jangka waktu tertentu yang telah disepakati oleh Para Pihak dalam akad murabahah, sehingga karenanya sebelum KONSUMEN membayar lunas kepada CNAF, maka KONSUMEN berhutang kepada CNAF. ${ }^{3}$

\section{Rumusan Masalah}

Dari uraian diatas maka permasalahan yang hendak di bahas dalam penelitian ini pertama, dalam hal apa saja terdapat perbedaan antara akad murabahah yang menerapkan prinsip syariah dengan perjanjian pembiayaan konsumen secara konvensional? Kedua, apakah kedudukan hukum Surat Kuasa untuk membuat Akta Jaminan Fidusia sudah memenuhi prinsip Syariah. Ketiga, bagaimanakah kekuatan hukum surat pernyataan bersama yang dibuat antara dealer dan perusahaan pembiayaan?

\section{Tujuan Penelitian}

Tujuan dari penelitian ini, pertama, untuk mengetahui hal apa saja terdapat perbedaan antara akad murabahah yang menerapkan prinsip syariah dengan perjanjian pembiayaan konsumen secara konvensional. Kedua, kedudukan hukum Surat Kuasa untuk membuat Akta Jaminan Fidusia sudah memenuhi prinsip Syariah. Ketiga, kekuatan hukum surat pernyataan bersama yang dibuat antara dealer dan perusahaan pembiayaan.

\section{Metode Penelitian}

12-2015, hlm 1-2.

2 Akad Pembiayaan Murabahah, PT CIMB Niaga auto Finance No. 416301501136, Rabu, 16-

${ }^{3}$ Ibid, hlm. 1 
Penelitian ini menggunakan pendekatan yuridis normatif yaitu menggunakan data sekunder sebagai data utamanya dan kemudian didukung data lapangan sebagai data primer yang diperoleh dari pejabat penyelenggara pertanahan. Selain itu, penelitian ini bersifat deskripsi analitis, bertujuan menggambarkan, menelaah, dan menganalisis secara sistematis suatu fakta tentang keadaan tertentu. Metode ini memiliki tujuan untuk memberikan gambaran yang sistematis, faktual serta akurat dari objek penelitian itu sendiri. Berdasarkan data yang terkumpul dilakukan analisis data dengan menggunakan metode normatif kualitatif untuk mengkaji data sekunder dan primer yang diperoleh dari lapangan.

\section{Hasil Penelitian dan Pembahasan}

\section{Pengertian Murabahah}

Kata al-Murabahah diambil dari bahasa Arab dari kata ar-ribhu (الرِبْحُ) yang berarti kelebihan dan tambahan (keuntungan), atau murabahah juga berarti Al-Irbaah karena salah satu dari dua orang yang bertransaksi memberikan keuntungan kepada yang lainnya (Ibnu Al-Mandzur., hal. 443.). sedangkan secara istilah, Bai'ul murabahah adalah:

Yaitu jual beli dengan harga awal disertai dengan tambahan keuntungan (Azzuhaili, 1997., hal. 3765). Definisi ini adalah definisi yang disepakati oleh para ahli fiqh, walaupun ungkapan yang digunakan berbeda-beda. (Asshawy, 1990., hal.198.)

Menurut Para ahli hukum Islam mendefinisikan bai' al-murabahah sebagai berikut

'Abd ar-Rahman al-Jaziri mendefinisikan bai' al-murabahah sebagai menjual barang dengan harga pokok beserta keuntungan dengan syarat-syarat tertentu.

Menurut Wahbah az-Zuhaili adalah jual-beli dengan harga pertama (pokok) beserta tambahan keuntungan.

Ibn Rusyd --filosof dan ahli hukum Maliki-- mendefinisikannya sebagai jual-beli di mana penjual menjelaskan kepada pembeli harga pokok barang yang dibelinya dan meminta suatu margin keuntungan kepada pembeli.

Ibn Qudamah --ahli hukum Hambali-- mengatakan bahwa arti jual-beli murabahah adalah jual-beli dengan harga pokok ditambah margin keuntungan.

Dengan kata lain, jual-beli murabahah adalah suatu bentuk jual-beli di mana penjual memberi tahu kepada pembeli tentang harga pokok (modal) barang dan pembeli membelinya berdasarkan harga pokok tersebut kemudian memberikan margin keuntungan kepada penjual sesuai dengan kesepakatan. Tentang "keuntungan yang disepakati”, penjual 
harus memberi tahu pembeli tentang harga pembelian barang dan menyatakan jumlah keuntungan yang ditambahkan pada biaya tersebut.

Para ahli hukum Islam menetapkan beberapa syarat mengenai jual-beli murabahah. Wahbah az-Zuhaili mengatakan bahwa di dalam bai' al-murabahah itu disyaratkan beberapa hal, yaitu:

1. Mengetahui harga pokok

Dalam jual-beli murabahah disyaratkan agar mengetahui harga pokok/ harga asal karena mengetahui harga merupakan syarat sah jual-beli. Syarat ini juga diperuntukkan untuk jual-beli at-tauliyyah dan al-wadi'ah.

2. Mengetahui keuntungan

Hendaknya margin keuntungan juga diketahui oleh si pembeli. Karena margin keuntungan termasuk bagian dari harga, sedangkan mengetahui harga merupakan syarat sah jual-beli.

3. Harga pokok merupakan sesuatu yang dapat diukur, dihitung dan ditimbang, baik pada waktu terjadi jual-beli dengan penjual yang pertama atau setelahnya, seperti dirham, dinar, dan lain-lain.

Jual-beli murabahah merupakan jual-beli amanah, karena pembeli memberikan amanah kepada penjual untuk memberitahukan harga pokok barang tanpa bukti tertulis. Dengan demikian, dalam jual-beli ini tidak diperbolehkan berkhianat.

Selain itu ada beberapa syarat-syarat sahnya jual beli murabahah adalah sebagai berikut:

a. Mengetahui Harga pokok

Harga beli awal (harga pokok) harus diketahui oleh pembeli kedua, karena mengetahui harga merupakan salah satu syarat sahnya jual beli yang menggunakan prinsip murabahah. Mengetahui harga merupakan syarat sahnya akad jual beli, dan mayoritas ahli figh menekankan pentingnya syarat ini. Bila harga pokok tidak diketahui oleh pembeli maka akad jual beli menjadi fasid (tidak sah) (Al-Kasany, hal.3193). Pada praktek perbankan syariah, Bank dapat menunjukkan bukti pembelian obyek jual beli murabahah kepada nasabah, sehingga dengan bukti pembelian tersebut nasabah mengetahui harga pokok Bank.

b. Mengetahui Keuntungan

Keuntungan seharusnya juga diketahui karena ia merupakan bagian dari harga. Keuntungan atau dalam praktek perbankan syariah sering disebut dengan margin 
murabahah dapat dimusyawarahkan antara bank sebagai penjual dan nasabah sebagai pembeli, sehingga kedua belah pihak, terutama nasabah dapat mengetahui keuntungan bank. c. Harga pokok dapat dihitung dan diukur.

Harga pokok harus dapat diukur, baik menggunakan takaran, timbangan ataupun hitungan. Ini merupakan syarat murabahah. Harga bisa menggunakan ukuran awal, ataupun dengan ukuran yang berbeda, yang penting bisa diukur dan di ketahui.

d. Jual beli murabahah tidak bercampur dengan transaksi yang mengandung riba.

e. Akad jual beli pertama harus sah.

Bila akad pertama tidak sah maka jual beli murabahah tidak boleh dilaksanakan. Karena murabahah adalah jual beli dengan harga pokok ditambah keuntungan, kalau jual beli pertama tidak sah maka jual beli murabahah selanjutnya juga tidak sah (Azzuhaily, hal. 3767-3770).

Undang-Undang No.21 Tahun 2008 tentang Perbankan Syariah memberikan definisi tentang murabahah dalam Penjelasan Pasal 19 ayat (1) huruf d. Menurut Penjelasan Pasal 19 ayat (1) huruf d tersebut, yang dimaksud dengan akad Murabahah adalah Akad Pembiayaan suatu barang dengan menegaskan harga belinya kepada pembeli dan pembeli membayarnya dengan harga yang lebih sebagai keuntungan yang disepakati. Dapat ditarik kesimpulan bahwa murabahah adalah jual-beli barang pada harga asal dengan tambahan keuntungan yang disepakati, penjual harus memberitahu harga produk yang ia beli dan menentukan suatu tingkat keuntungan sebagai tambahannya. Murabahah merupakan salah satu bentuk dari jual- beli yang bersifat amanah, murabahah terlaksana antara penjual dan pembeli berdasarkan harga barang, harga asli pembelian penjual yang diketahui oleh pembeli dan keuntungan penjual pun diberitahukan kepada pembeli.

Undang - undang No. 10 tahun 1998 tentang Perbankan, memberikan paying hukum bagi berlakunya pembiayaan berdasarkan prinsip syariah, hal ini tertuang dalam pasal 6 huruf $m$, yang berbunyi :

"menyediakan pembiayaan dan atau melakukan kegiatan lain berdasarkan prinsip syariah sesuai dengan ketentuan yang ditetapkan oleh Bank Indonesia”

Ketentuan Bank Indonesia yang dimaksud adalah SK Direksi Bank Indonesia No. 32/34/KEP/DIR/1999 tentang Bank Umum berdasarkan prinsip syariah, dalam perjalanannya SK Direksi kemudian diubah dengan Peraturan Bank Indonesia Nomor 
2/27/PBI/2000. Selain itu, masih banyak lagi peraturan-peraturan yang dikeluarkan Bank Indonesia terkait pembiayaan berdasarkan prinsip syariah.Disamping berbagai peraturan BI, Kitab Undang-undang Hukum Pedata juga menjadi pendamping dalam pelaksanaan pembiayaan murabahah, terutama berkaitan dengan syarat sahnya perjanjian, waktu berakhirnya perjanjian,dan sebagainya. Diberlakukannya UU No.10 tahun 1998 memberikan landasan hukum yang kuat terhadap perkembangan system perbankan syariah di Indonesia. Hal ini merupakan suatu perubahan yang signifikan terhadap undang - undang perbankan sebelumnya. Salah satu prinsip yang dipegang dalam pengaturan tentang Bank Syariah dalam UU No.10 tahun 1998 ini adalah bahwa prinsip syariah merupakan suatu prinsip dalam menjalankan kegiatan usaha bank, sehingga bukan merupakan jenis kelembagaan melainkan cara menjalankan usaha bank.

\section{Perbedaan Pembiayaan Akad Murabahah Syariah dengan Perjanjian Pembiayaan Konsumen Konvensional}

\section{Pembiayaan Akad Murabahah}

Semua transaksi dalam muamalah Islam pada prinsipnya diperbolehkan kecuali yang diharamkan. Transaksi secara sederhana diartikan sebagai peralihan hak dan kepemilikan dari satu tangan ke tangan lain. Hal ini merupakan suatu cara dalam memperoleh harta disamping mendapatkan sendiri sebelum menjadi milik seseorang dan merupakan cara yang paling lazim dalam mendapatkan hak. Secara umum di dalam Al-Qur'an transaksi diartikan sebagai tijarah. Cara brlangsungnya tijarah yang sesuai dengan kehendak Allah adalah menurut prinsip suka sama suka, terbuka, dan bebas dari unsur penipuan. Sebagaimana tertuang dalam QS. An-Nisa (4):29. ${ }^{4}$

Murabahah adalah transaksi penjualan barang dengan menyatakan harga perolehan dan keuantungan (margin) yang disepakati oleh penjual dan pembeli. Pembayaran atas akad dapat dilakukan dengan cara tunai (bai 'naqdan) atau tangguh (bai 'Mu'ajjal / bai' Bi 'tsaman Ajil). Selain itu Murabahah juga dimaknai sebagai akad jual beli barang pada harga asal dengan tambahan keuntungan yg disepakati. Penjual harus memberi tahu harga produk yg ia beli dan menentukan suatu tingkat keuntungan sebagai tambahannya. Jual beli ini dpt dilakukan secara memesan yg disebut dengan Murabahah kepada pemesan pembeli ( KPP). Menurut Imam Syafii disebut al- aamir bisy-syira' (kitab al- umm).

\footnotetext{
${ }^{4}$ Yudhit Nitriasari, 2014, Kajian Prinsip Syariah dalam Pembiayaan Pemilikan Kendaraan Bermotor pada FIF Syariah di Daerah Istimewa Yogyakarta, MKn-Program Paca sarjana-UGM , hlm 25-26.
} 
Ketentuan Pasal 20 ayat (6) Peraturan Mahkamah Agung No. 2 Tahun 2008 tentang Kompilasi Hukum Ekonomi Syariah menyatakan bahwa Murabahah adalah pembiayaan $\underline{\text { saling menguntungkan yang dilakukan oleh shahib al-mal (pemilik modal) dengan pihak }}$ yang membutuhkan melalui transaksi jual beli dengan penjelasan bahwa harga pengadaan barang dan harga jual terdapat nilai lebih yang merupakan keuntungan atau laba bagi shahib al-mal dan pengembaliannya dilakukan secara tunai atau angsur.

Hal yang membedakan antara murabahah dengan penjualan yang kita kenal adalah penjual secara jelas memberitahu kepada pembeli berapa harga pokok tersebut dan berapa besar keuntungan yang diinginkannya. Secara umum para ulama memperbolehkan pembebanan biaya langsung yang harus dibayarkan kepada pihak ketiga. Mereka tidak memperbolehkan pembebanan biaya langsung yang berhubungan dengan pekerjaan yang memang harus dilakukan oleh penjual, dan biaya tidak langsung yang tidak menambahkan nilai barang (Karim,2003).

Jenis Akad Murabahah :

1. Murabahah dengan pesanan

Murabahah jenis ini, penjual melakukan pembelian barang setelah ada pesanan dari pembeli.

2. Murabahah tanpa pesanan (tidak mengikat)

Adapun Rukun dan ketentuan Murabahah yaitu :

a. Pelaku

b. Objek Jual Beli Harus memenuhi :

1) Barang yang diperjual belikan adalah barang halal;

2) Barang yang diperjual belikan harus dapat diambil manfaatnya atau memiliki nilai;

3) Barang tersebut dimiliki oleh penjual;

4) Barang tersebut dapat diserahkan tanpa tergantung dengan kejadian tertentu dimasa depan ;

5) Barang tersebut harus diketahui secara spesifik dan dapat diidentifikasi oleh pembeli sehingga tidak ada gharar (ketidak pastian);

6) Barang tersebut dapat diketahui kuantitasnya dengan jelas;

7) Barang tersebut dapat diketahui kualitasnya dengan jelas sehingga tidak ada gharar;

8) Harga barang tersebut jelas;

9) Barang yang diakadkan secara fisik ada ditangan penjual.

c. Ijab Kobul. 


\section{Perjanjian Pembiayaan Konsumen Kendaraan Bermotor}

Pembiayaan Konsumen (Consumer Finance) adalah suatu usaha yang melakukan kegiatan pembiayaan untuk pengadaan barang berdasarkan kebutuhan konsumen dengan sistem pembayaran angsuran, biasa disebut barang konsumsi. Pembiayaan konsumen membiayai barang-barang yang bersifat konsumtif yaitu kendaraan bermotor (mobil dan motor), barang elektronik, perumahan dan alat-alat rumah tangga.

Menurut Pasal 1 huruf (g) Peraturan Menteri Keuangan Republik Indonesia Nomor 84/PMK.012/2006 tentang pengertian Pembiayaan Konsumen adalah: Kegiatan pembiayaan untuk pengadaan barang berdasarkan kebutuhan konsumen dengan pembayaran secara berkala. Berdasarkan definisi diatas unsur-unsur yang terkandung dalam pembiayaan konsumen adalah sebagai berikut: ${ }^{5}$

1. Subyek adalah pihak-pihak yang terkait dalam hubungan hukum pembiayaan konsumen, yaitu perusahaan pembiayaan konsumen (kreditor), konsumen (debitor), dan penyedia barang (pemasok/supplier)

2. Obyek adalah barang bergerak keperluan konsumen yang akan dipakai untuk keperlun hidup atau keperluan rumah tangga.

3. Perjanjian, yaitu perbuatan persetujuan pembiayaan yang diadakan antara perusahaan pembiayaan konsumen dan konsumen, serta jual beli antara pemasok dan konsumen.

4. Hubungan hak dan kewajiban, yaitu perusahaan pembiayaan konsumen wajib membiayai harga pembelian barang yang diperlukan konsumen dan membayarnya secara tunai kepada pemasok. Konsumen wajib membayar secara angsuran kepada perusahaan pembiayaan konsumen, dan pemasok wajib menyerahkan barang kepada konsumen.

5. Jaminan, yaitu terdiri atas jaminan utama, jaminan pokok dan jaminan tambahan.

a. Jaminan utama berupa kepercayaan dari perusahaan pembiayaan konsumen kepada konsumen bahwa pihak konsumen dapat dipercaya dan sanggup membayar secara berkala atau angsuran sampai lunas.

b. Jaminan pokok digunakan untuk lebih mengamankan dana yang telah diberikan kepada konsumen, perusahaan pembiayaan biasanya meminta jaminan pokok berupa barang yang dibeli dengan dana dari perusahaan pembiayaan misalnya digunakan untuk membeli kendaraan bermotor, maka kendaraan bermotor yang bersangkutan

\footnotetext{
${ }^{5}$ Abdulkadir Muhammad dan Rilda Murniati, Segi Hukum Lembaga Keuangan dan Pembiayaan, (Bandung : Citra Aditya Bakti, 2000), hlm. 228
} 
menjadi jaminan pokoknya. Akan tetapi jaminan tersebut dibuat dalam bentuk fidusia berupa barang yang dibiayai oleh perusahaan pembiayaan konsumen dimana semua dokumen kepemilikan barang dikuasai oleh perusahaan pembiayaan konsumen sampai angsuran terakhir dilunasi.

c. Jaminan tambahan berupa pengakuan utang dari konsumen atau kuasa menjual barang dan dimintakan persetujuan istri/suami untuk konsumen pribadi dan persetujuan komisaris/RUPS untuk konsumen perusahaan, sesuai dengan ketentuan anggaran dasarnya

\section{Dasar Hukum Pembiayaan Konsumen (Sudut pandang Hukum Perdata):}

Perjanjian pembiayaan konsumen merupakan dokumen hukum utama yang dibuat secara sah memenuhi syarat-syarat yang ditetapkan dalam Pasal 1320 KUHPerd. Akibat hukum perjanjian yang dibuat secra sah berlaku sebagai undang-undng dari perusahaan pembiayaan konsumen dan konsumen itu sendiri sebagaimana diatur dalam pasa 1338 ayat (1) KUHPerd. Konsekuensi yuridis selanjutnyam perjanjian harus dilaksanakan dengan

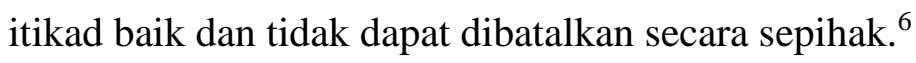

\section{Bentuk Perjanjian Pembiayaan Konsumen}

Bentuk perjanjian pembiayaan konsumen yaitu perjanjian baku berasal dari terjemahan dari bahasa Inggris yaitu standart contract. Standar kontrak merupakan perjanjian yang telah ditentukan dan telah dituangkan dalam bentuk formulir. Penyusunan perjanjian baku telah ditentukan secara sepihak oleh salah satu pihak, terutama pihak ekonomi kuat, sedangkan pihak lainnya hanya diminta untuk menerima atau menolak isinya. Apabila debitur menerima isinya perjanjian tersebut, ia menandatangani perjanjian, tetapi apabila menolak, perjanjian itu dianggap tidak ada karena debitur tidak menandatangani perjanjian tersebut. Dari subyek yang akan melakukan perjanjian, dalam membuat asas kebebasan berkontrak para pihak bebas untuk membuat atau tidak membuat perjanjian, bebas menentukan "apa" dan "dengan siapa" perjanjian itu diadakan dan bebas menentukan isi dari 44 perjanjian. Bentuk perjanjian baku yang telah baku dapat mengurangi implementasi kebebasan berkontrak, karena isi perjanjian telah disusun oleh perusahaan.

Berikut letak beda antara Akad Murabahah (secara Prinsip Syariah) dengan Perjanjian Pembiayaan (secara konvensional):

\footnotetext{
${ }^{6}$ Ibid, hlm. 32
} 


\begin{tabular}{|c|c|c|}
\hline Letak Beda & Akad Murabahah & Perjanjian Pembiayaan \\
\hline $\begin{array}{l}\text { Dasar } \\
\text { Hukum }\end{array}$ & $\begin{array}{l}\text { Dijalankan dengan melihat aturan } \\
\text { atau prinsip syariah yang berlaku } \\
\text { disamping berpedoman pada aturan } \\
\text { hukum yang sifatnya konvensional. }\end{array}$ & $\begin{array}{l}\text { Dijalankan dengan melihat } \\
\text { aturan yang sifatnya } \\
\text { konvensional seperti aturan } \\
\text { UU, KUHPerdata maupun } \\
\text { aturan hukum lainnya. }\end{array}$ \\
\hline Isi Akad & $\begin{array}{l}\text { Harus terhindar dari unsur Riba. } \\
\text { Sehingga dalam hal ini pihak lembaga } \\
\text { pembiayaan ataupun perbankan } \\
\text { menjual barang kepada nasabah } \\
\text { (pemesan) dengan harga jual yang } \\
\text { senilai dengan harga beli ditambah } \\
\text { dengan keuntungannya. Bank harus } \\
\text { memberitahu secara jujur harga } \\
\text { pokok barang kepada nasabah berikut } \\
\text { biaya yang diperlukan. }\end{array}$ & $\begin{array}{lr}\text { Dalam praktek bisa saja pihak } \\
\text { lembaga } & \text { pembiayaan } \\
\text { konvensional } & \text { ataupun } \\
\text { perbankan konvensional yang } \\
\text { menjalankan } & \text { kegiatan } \\
\text { pembiayaan } & \text { menerapkan } \\
\text { bunga dalam } & \text { angka yang } \\
\text { cukup tinggi dan kadang } & \text { dan } \\
\text { berubah-ubah. Hal yang } \\
\text { demikian dapat saja } \\
\text { memberatkan nasabah. }\end{array}$ \\
\hline Jaminan & $\begin{array}{l}\text { Berdasarkan Fatwa } r \text { DSN } \\
\text { No.04/DSN-MUI/IV/2000 Tentang } \\
\text { Murabahah menyatakan bahwa } \\
\text { jaminan dalam murabahah } \\
\text { dibolehkan, agar nasabah serius } \\
\text { dengan pesanannya. Hal yang } \\
\text { demikian dapat diartikan bahwa } \\
\text { dalam murabahah nasabah tidak } \\
\text { diwajibkan untuk menyediakan } \\
\text { jaminan. Namun lembaga } \\
\text { pembiayaan atau perbankan dapat dan } \\
\text { diperbolehkan untuk meminta } \\
\text { jaminan kepada nasabahnya. }\end{array}$ & $\begin{array}{l}\text { Dalam hal ini jaminan menjadi } \\
\text { suatu hal yang diwajibkan } \\
\text { untuk dilakukan oleh nasabah. }\end{array}$ \\
\hline $\begin{array}{l}\text { Penyelesaian } \\
\text { Perselisihan }\end{array}$ & $\begin{array}{l}\text { Biasanya sesuai dengan isi akad. Jika } \\
\text { merujuk pada Pasal 55 UU No. } 21 \\
\text { tahun } 2008 \text { tentang Perbankan Syariah } \\
\text { maka yang dimaksud dengan Sesuai } \\
\text { Isi Akad bahwa penyelesaian } \\
\text { dilakukan musyawarah; mediasi } \\
\text { perbankan; melalui Badan Arbitrase } \\
\text { Syariah Nasional (Basyarnas) atau } \\
\text { lembaga arbitrase lain; dan/atau } \\
\text { melalui pengadilan dalam lingkungan } \\
\text { Peradilan Umum. (PA atau PN) }\end{array}$ & $\begin{array}{l}\text { Sedangkan untuk pembiayaan } \\
\text { konvensional dapat dilakukan } \\
\text { melalui jalur pengadilan } \\
\text { umum (PN) atau Arbitrase } \\
\text { Konvensional. }\end{array}$ \\
\hline
\end{tabular}

\section{Kedudukan Surat Kuasa untuk Membuat Akta Jaminan Fidusia}

\section{a. Jaminan Fidusia}


Fidusia jika diartikan menurut Pasal 1 ayat (1) UU No. 42 Tahun 1999 tentang Jaminan Fidusia adalah pengalihan hak kepemilikan suatu benda atas dasar kepercayaan dengan ketentuan bahwa yang hak kepemilikannya dialihkan tersebut tetap dalam penguasaan pemilik benda.

Sebelum fidusia mendapat pengakuan dalam yurisprudensi, pemberian jaminan bergerak dengan tanpa melepaskan benda jaminan yang bersangkutan dari kekuasaan pemberi jaminan sebenarnya sudah dikenal dan diakui oleh undang-undang di waktu yang lalu, tetapi tidak dalam bentuk penyerahan hak milik secara kepercayaan, tetapi dalam bentuk ikatan panen/oogstverband (S.1886:57) ${ }^{7}$

Adapun sifat dan ciri - ciri dari fidusia antara lain: ${ }^{8}$

1) Perjanjian fidusia merupakan perjanjian obligatoir.

Hak yang penerima fidusia peroleh merupakan hak milik yang sepenuhnya, meskipun hak tersebut dibatasi hal-hal yang ditetapkan bersama dalam perjanjian.

2) Sifat acessoir dari perjanjian jaminan fidusia

Perjanjian fidusia merupakan perjanjian yang bersifat accessoir yang adanya tergantung pada perjanjian pokok yang berupa peminjaman uang, perjanjian kredit oleh bank. Maka dalam kedudukannya sebagai perjanjian yang bersifat accessoir, lembaga jaminan fidusia itu dapat menimbulkan hak yang zakelijk (hak kebendaan) seperti halnya hipotik, creditverband dan pand. ${ }^{9}$ Sebagai suatu perjanjian acessoir, perjanjian jaminan fidusia memiliki sifat sebagai berikut:

a) Sifat ketergantungan terhadap perjanjian pokok;

b) Keabsahannya semata-mata ditentukan oleh sah tidaknya perjanjian pokok; dan

7 bermula dari terjadinya krisis pertanian yang melanda negara-negara Eropa pada pertengahan sampai akhir abad ke-19, terjadi penghambatan pada perusahaan-peusahaan pertanian untuk memperoleh kredit. Tanah sebagai jaminan kredit agak kurang populer dan kreditor menghendaki jaminan gadai sebagai jaminan tambahan disamping jaminan tanah tadi. Untuk mengatasi hal tersebut maka dilakukan penerobosan yaitu jual-beli dengan hak membeli kembali dengan sedikit penyimpangan. Keadaan tersebut berlangsung sampai dikeluarkannya keputusan Hoge Raad (HR) Belanda tanggal 29 Januari 1929 yang terkenal dengan nama Bierbrouwerij Arrest. Hal ini telah melahirkan pranata jaminan dengan jaminan penyerahan hak milik secara kepercayaan yang dikenal dengan fidusia yang keberadaannya didasarkan pada jurisprudensi. Selain itu lahirlah peraturan tentang ikatan panen atau oogstverband (S.1886 Nomor 57) yang mengatur mengenai peminjaman uang, yang diberikan dengan jaminan panenan yang akan diperoleh dari suatu perkebunan. Lihat pada J.Satrio, Hukum Jaminan Hak Jaminan Kebendaan Fidusia, PT. Citra Aditya Bakti, Bandung, 2002, hlm.124-125. Lihat juga Gunawan Widjaja \& Ahmad Yani, Seri Hukum Bisnis Jaminan Fidusia, Rajawali Pers, Jakarta, 2001, hlm.113-118

8 Rachmadi Usman, Hukum Jaminan Keperdataan, Sinar Grafika, Jakarta, 2008, hlm.162-171

${ }^{9}$ Sri Soedewi Masjchun Sofwan, Himpunan Karya Tentang Jaminan, Liberty, Yogyakarta, 1982, hlm. 83 
c) Sebagai perjanjian bersyarat, maka hanya dapat dilaksanakan jika ketentuan yang disyaratkan dalam perjanjian pokok telah atau tidak dipenuhi.

3) Sifat droit de suite dari fidusia sebagaimana ketentuan Pasal 20 UU Fidusia.

4) Sifat droit de preference bahwa fidusia memberikan kedudukan diutamakan sebagaimana ketentuan Pasal 27 dan 28 UU Fidusia.

Pemberian jaminan dalam perbankan konvensional merupakan suatu keharusan dalam penyaluran kredit, sedangkan dalam perbankan syariah khususnya dalam pembiayaan, jaminan boleh dimintakan atau tidak dimintakan dari nasabah karena nasabah dalam hal ini berstatus sebagai mitra kerja dalam hubungan kemitraan. ${ }^{10}$

Jaminan atau agunan ini timbul dikarenakan adanya perjanjian pembiayaan antara nasabah dan bank, tetapi sering kali masalah timbul dalam pengembalian dana yang dipinjam itu, nasabah lalai dalam mengembalikan dana tersebut. Guna memastikan pengembalian dana bank dibutuhkan jaminan ${ }^{11}$. Jadi hak tagih bank dijamin dengan barang nasabah yang sudah ada pada saat terjadinya perjanjian pembiayaan. Dengan adanya jaminan maka menimbulkan hak yang diutamakan bagi bank dalam pelunasan pembiayaannya, sebagaimnana diatur dalam Pasal 1131KUHPerdata, yang menyatakan:

"segala kebendaan si berutang, baik yang bergerak maupun tidak bergerak, baik yang sudah ada maupun yang baru akan ada dikemudian hari, menjadi tanggungan untuk segala perikatan perseorangan”.

\section{b. Fidusia dalam Hukum Islam}

Jika dalam hukum positif permasalahan di atas dimasukkan dalam pembahasan mengenai fidusia, maka dalam hukum Islam jaminan fidusia dikategorikan dalam Rahn Tasjily. Esensi Rahn Tasjily sendiri identik dengan jaminan fidusia, karena definisi dari Rahn Tasjily adalah jaminan dalam bentuk barang atas hutang tetapi barang jaminan tersebut (marhun) tetap berada dalam penguasaan (pemanfaatan) rahin dan bukti kepemilikannya diserahkan kepada murtahin.1 Fatwa DSN-MUI No. 68/DSN-MUI/III 2008 telah mengatur mengenai Rahn Tasjily berikut ketentuan penyitaannya yang berbunyi "penyimpangan barang jaminan dalam bentuk bukti yang sah kepemilikan atau sertifikat tersebut tidak memindahkan kepemilikan barang ke murtahin. Apabila terjadi wanprestasi atau tidak dapat

\footnotetext{
${ }^{10}$ http://lontar.ui.ac.id/opac/themes/libri2/detal,jsp?id=20251855\&lokasi=lokal, Humaira Ridanty, Pemberian Jaminan Fidusia Dengan Akta Notaris Pada pembiayaan Musyarakah di Perbankan Syariah (Studi PT. Bank XX Jakarta), Abstrak Tesis,Perpus UI.

11 Andy Lesmana, Pemberian Jaminan Fidusia Dengan Akta Notaris Dalam Kaitannya Dengan Pembiayaan Murabahah Pada Perbankan Pada perbankan Syariah Khususnya di Bank Danamon Syariah, Tesis Program Magister Kenotariatan-UNPAD, Bandung, 2010, hlm. 14-15.
} 
melunasi hutangnya, marhun dapat dijual paksa atau dieksekusi langsung baik melalui lelang atau dijual ke pihak lain sesuai prinsip syariah."12

Jaminan dalam Islam biasanya diatur dalam bab rahn, rahn yang secara etimologi memiliki arti tetap atau kontinyu ini memiliki banyak definisi yang lainnya. Rahn juga memiliki arti lain yaitu tertahan, seperti terdapat dalam al-Qur'an surat Muddatstsir ayat 38

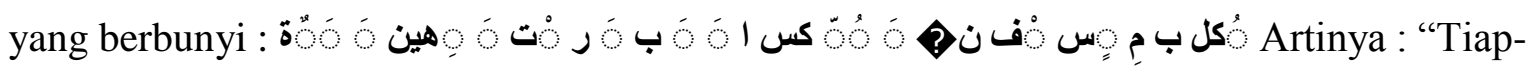
tiap diri bertanggung jawab (tertahan) atas apa yang telah diperbuatnya."(Q.S. AlMuddatstsir:38) Kata rahinah disini diartikan tertahan, ${ }^{\mathbf{1 3}}$ sebagaimana kita ketahui barang jaminan gadai biasanya dikuasai oleh debitur. Sedangkan dalam kamus istilah keuangan dan perbankan syariah Bank Indonesia Direktorat Perbankan Syariah mengartikan rahn adalah penyerahan barang sebagai jaminan untuk mendapatkan hutang. Rahn atau lebih dikenal dengan gadai memiliki definisi dalam terminologi fiqh secara umum yaitu menahan suatu barang dengan suatu hak yang memungkinkan dapat dipenuhi dari barang tersebut, artinya barang tersebut dijadikan penguat atau jaminan terpenuhinya hak. ${ }^{\mathbf{1 4}}$

\section{c. Kedudukan Surat Kuasa dalam membuat Akta Jaminan Fidusia}

Surat kuasa adalah surat pemberian kuasa atau wewenang terhadap seseorang yang dapat dipercaya agar yang bersangkutan dapat bertindak mewakili orang yang memberi kuasa karena orang yang memberi kuasa tidak dapat melaksanakan sendiri. ${ }^{15}$ Fungsinya adalah sebagai salah satu bukti bahwa orang yang disebutkan namanya di dalam surat tersebut berhak atau berkewajiban untuk melakukan sesuai dengan isi surat kuasa.

Dalam kuliah yang disampaikan Bapak Agus Triyanta, akad syariah tidak boleh bertentangan dengan hukum positif Indonesia, selain itu "prinsip muamalah adalah mubah kecuali ada larangannya”. Sehingga dari pernyataan-pernyataan yang kami kutip dapat kami simpulkan bahwa surat kuasa dalam pembiayaan konsumen yang berrprinsip syariah

${ }^{12} \mathrm{http}: / /$ download.portalgaruda.org/article.php?article=339797\&val=5276\&title=IMPLEMENTASI \%20PRINSIP\%20SYARIAH\%20TERHADAP\%20PENYITAAN\%20\%20JAMINAN\%20FIDUSIA, Iffaty Nasyi'ah dan Asna Jazillatul Chusna, Implementasi Prinsip Syariah Terhadap Tenyitaan Jaminan Fidusia,

${ }^{13}$ Abdullah bin Muhammad ath-Thayar, Prof. Dr. Abdullah bin Muhammad al-Muthliq, dan Dr. Muhammad bin Ibrahim Alu Musa, Al-Fiqh AlMuyassarah, Qismul Mu'amalah, (cetakan pertama, tahun 1425 $\mathrm{H}$,

${ }^{14}$ Wahbah Al-Zuhaili, Al-Mu'amalat Al-Maliyyah AlMu'ashirah Buhuts Wa Fatawa Wa Hulul, (Beirut: Dar AlMu'ashirah, 2002), h. 82.

${ }^{15}$ Suparjati, dkk, Surat-Menyurat Dalam Perkantoran, Kanisius, Yogyakarta, 2000, hlm.42. 
diperbolehkan sepanjang tidak dilarang dan tidak mencederai asas-asas kepatutan dan itikad baik.

Pasal 5 ayat 1 UUJF menyebutkan bahwa Pembebanan Benda dengan Jaminan Fidusia dibuat dengan akta notaris dalam Bahasa Indonesia dan merupakan Akta Jaminan Fidusia, selanjutnya dipertegas dalam penjelasanya yang menyebutkan bahwa Dalam Akta Jaminan Fidusia selain mencantumkan hari dan tanggal, juga mencantumkan waktu (jam) pembuatan akta tersebut.

Dalam lampiran yang dilekatkan dalam akad murabahah salah satunya adalah Surat Kuasa Penuh dengan hak substitusi kepada PT. CNAF oleh konsumen, untuk melakukan pembebanan jaminan secara fidisia pada “Obyek Jaminan Fidusia”, yaitu mobil Honda BrioSatya E MT/City Car/2015. Akta Jaminan Fidusia dibuat dengan akta notariil. Kedudukan Surat Kuasa dalam prinsip syariah tidak ada beda dengan kedudukan surat kuasa pada perjanjian umumnya. Hal ini dikarenakan surat kuasa merupakan surat yang ditandatangani oleh perwakilan dari salah satu pihak yang karena dengan alasan tertentu tidak dapat hadir dalam proses penandatanganan atau pembuatan perjanjian dihadapan notaris.

Surat kuasa ini tidak harus dibuat dalam bentuk akta notariil, akan tetapi sebaiknya dilegalisasi oleh notaris. Dilegalisasi di sini artinya, penandatanganan surat kuasa tersebut dilakukan di hadapan notaris. Jadi, bentuknya bukan akta notaris, akan tetapi ada notaris yang menyaksikan penandatanganan surat kuasa tersebut. Surat kuasa yang lazim ditandatangani dalam pengikatan jaminan fidusia dalam dunia perbankan adalah surat kuasa untuk mendaftarkan jaminan fidusia. Surat kuasa untuk mendaftarkan jaminan fidusia ini antara lain disebut dalam Pasal 13 ayat (2) UU Fidusia dan Pasal 2 ayat (4) PP No. 86 Tahun 2000 tentang Tata Cara Pendaftaran Jaminan Fidusia Dan Biaya Pembuatan Akta Jaminan Fidusia (“PP No. 86/2000"). ${ }^{16}$

\section{Kekuatan hukum Surat Pernyataan Bersama yang dibuat antara Dealer dengan}

\section{Konsumen}

Dalam akad pembiayaan murabahah No. 4163015001136, terdapat lampiran Surat Pernyataan Bersama antara Tuan Budi Santoso, SE dalam jabatannya selaku Branch Manager, dalam hal ini bertindak mewakili Tunas Mobil, PT-SOETTA 9 Magelang-Yog, yang berkedudukan di Magelang (Penjual) dengan Ny. Muntakiyah (Konsumen). Dalam

16 http://www.hukumonline.com/klinik/detail/lt4c6cdcb7c88c7/surat-kuasa-fidusia-di-bawahtangan diakses pada Senin, 18 Januari 2016 
surat pernyataan yang dibuat merupakan akta dibawah tangan dan di tanda tangani pihak Penjual, Konsumen dan Branch Manager dari PT. CNAF. (isi SPB dapat dilihat dalam lampiran tulisan ini).

Surat Pernyataan adalah pernyataan seseorang terhadap adanya suatu hal. Adapun kekuatan hukum dari sebuah surat pernyataan di bawah tangan agar dapat digunakan sebagai alat pembuktian mengenai perbuatan, kenyataan atau keadaan yang bersifat perdata maka surat pernyataan tersebut ditandatangani di atas materai Rp. 6000,- (Pasal 2 ayat (1) huru a UU No. 13 Tahun 1985 tentang Bea Materai jo. Pasal 2 ayat (10 PP No. 24 Tahun 2000 tentang Perubahan Tarif Bea Materai dan Besarnya Batas Pengenaan Harga Nominal yang Dikenakan Bea Materai). ${ }^{17}$

Untuk akta di bawah tangan pemeriksaan yang paling pertama dilakukan oleh hakim adalah mengenai benar tidaknya akta yang bersangkutan telah ditandatangani oleh pihak(pihak) yang bersangkutan. Akta di bawah tangan yang diakui isi dan tanda tangannya, memiliki kekuatan pembuktian yang sempurna seperti suatu akta otentik (lihat pasal 1875 KUHPerdata. Lihat juga Putusan Mahkamah Agung: tanggal 3-12-1974 No. 1043 K/Sip/1971). Jadi, selama tidak disangkal, akta di bawah tangan memiliki kekuatan pembuktian yang sama seperti akta otentik. ${ }^{18}$

\section{Penutup}

Hasil penelitian menyimpulkan, pertama, pada dasarnya tidak ada perbedaan yang terlalu mendasar antara akad murabahah yang dilakukan pada lembaga-lembaga pembiayaan atau Perbankan syariah dengan perjanjian pembiayaan konsumen yang dijalankan secara konvensional. Perbedaan mendasar bisa lebih terlihat pada dasar hukum dalam menjalankan yang sifatnya konvensional maupun yang sifatnya syariah. Menjalankan akad murabahah ternyata dapat juga dijalankan oleh lembaga pembiayaan maupun perbankan yang konvensional tanpa ada kata "syariah" dibelakang nama lembaga atau perbankan tersebut. Hal tersebut tidak menjadi suatu hal yang dipermasalahkan sepanjang lembaga pembiayaan maupun perbankan konvensional yang menjalankan praktik pembiayaan syariah sesuai dengan landasan dan prinsip syariah di dalamnya. Kedua, perbedaan lain yang cukup terlihat dalam suatu akad murabahah dengan perjanjian

\footnotetext{
${ }^{17}$ www.hukumonline.com, Amrie Hakim, SH, "Surat Pernyataan Bermaterai", Rabu, 22 Desember 2010.

18 Ibid.
} 
pembiayaan konsumen secara konvensional, bahwasanya akad murabahah tidak mewajibkan adanya jaminan yang harus disediakan oleh nasabahnya hal tersebut dapat dilihat pada Fatwa DSN-MUI mengenai akad murabahah sedangkan pada perjanjian pembiayaan pada umumnya biasanya peletakan jaminan seakan menjadi suatu hal yang sifatnya wajib mengingat dalam suatu konsep hukum konvensional jaminan merupakan perjanjian tambahan yang mengikuti perjanjian pokok. Ketiga, Kedudukan Surat Kuasa di dalam prinsip syariah diperbolehkan sepanjang tidak bertentangan dengan hukum positif Indonesia, tidak di larang, dan jelas kegunaannya juga tidak mencederai asas-asaskepatutan dan itikad baik.

\section{Daftar Pustaka}

\section{BUKU-BUKU:}

Abdullah bin Muhammad ath-Thayar, Prof. Dr. Abdullah bin Muhammad al-Muthliq, dan Dr. Muhammad bin Ibrahim Alu Musa, Al-Figh AlMuyassarah, Qismul Mu'amalah, cetakan pertama, tahun $1425 \mathrm{H}$

Abdulkadir Muhammad dan Rilda Murniati, Segi Hukum Lembaga Keuangan dan Pembiayaan, Bandung : Citra Aditya Bakti, 2000

Gunawan Widjaja \& Ahmad Yani, Seri Hukum Bisnis Jaminan Fidusia, Rajawali Pers, Jakarta, 2001

Rachmadi Usman, Hukum Jaminan Keperdataan, Sinar Grafika, Jakarta, 2008.

Sri Soedewi Masjchun Sofwan, Himpunan Karya Tentang Jaminan, Liberty, Yogyakarta, 1982

Suparjati, dkk, Surat-Menyurat Dalam Perkantoran, Kanisius, Yogyakarta, 2000

Wahbah Al-Zuhaili, Al-Mu'amalat Al-Maliyyah AlMu'ashirah Buhuts Wa Fatawa Wa Hulul, Beirut: Dar AlMu'ashirah, 2002

\section{PERATURAN PERUNDANG-UNDANGAN:}

Undang-Undang No.42 Tahun 1999 Tentang Jaminan Fidusia

Undang-Undang No. 21 Tahun 2008 Tentang Perbankan Syariah

Peraturan Mahkamah Agung No. 02 Tahun 2008 Tentang Kompilasi Hukum Ekonomi Syariah

Fatwa DSN-MUI No. 04/DSN-MUI/IV/2000 Tentang MURABAHAH

\section{TESIS :}

Yudhit Nitriasari, Kajian Prinsip Syariah dalam Pembiayaan Pemilikan Kendaraan Bermotor pada FIF Syariah di Daerah Istimewa Yogyakarta, Tesis MKn-Program Paca sarjana-UGM, Yogyakarta, 2014 
Andy Lesmana, Pemberian Jaminan Fidusia Dengan Akta Notaris Dalam Kaitannya Dengan Pembiayaan Murabahah Pada Perbankan Pada perbankan Syariah Khususnya di Bank Danamon Syariah, Tesis Program Magister KenotariatanUNPAD, Bandung, 2010

\section{INTERNET:}

http://lontar.ui.ac.id/opac/themes/libri2/detal,jsp?id=20251855\&lokasi=lokal, Humaira Ridanty, Pemberian Jaminan Fidusia Dengan Akta Notaris Pada pembiayaan Musyarakah di Perbankan Syariah (Studi PT. Bank XX Jakarta), Abstrak Tesis,Perpus UI

http://www.hukumonline.com/klinik/detail/lt4c6cdcb7c88c7/surat-kuasa-fidusia-dibawah-tangan diakses pada Senin, 18 Januari 2016

www.hukumonline.com, Amrie Hakim, SH, "Surat Pernyataan Bermaterai", Rabu, 22 Desember 2010. 